\title{
Clay mineralogy and magnetic susceptibility of Oxisols in geomorphic surfaces
}

\author{
Livia Arantes Camargo, José Marques Júnior*, Gener Tadeu Pereira, Angélica Santos Rabelo de Souza Bahia
}

São Paulo State University/FCAV, Via de Acesso Prof. Paulo Donato Castellane, $s / n^{\circ}-14884-900$ - Jaboticabal, SP Brazil.

*Corresponding author <marques@fcav.unesp.br>

Edited by: Thomas Jot Smyth

Received June 19, 2013

Accepted December 10, 2013
ABSTRACT: Studies analyzing the variability of clay minerals and magnetic susceptibility provide data for the delineation of site-specific management areas since many of their attributes are important to agronomy and the environment. This study aimed to evaluate the spatial variability of clay minerals, magnetic susceptibility, adsorbed phosphorus and physical attributes in Oxisols of sandstones in different geomorphic surfaces. For that purpose, soil samples were collected every $25 \mathrm{~m}$ along a transect located within the area where the geomorphic surfaces were identified and mapped. The transect occupied the central portion of 500 ha, where it was also sampled for density purposes with one sample per six hectares. Soil samples were collected at a depth of 0.0-0.2 m. The results of the physical, chemical, mineralogical and magnetic susceptibility analyses were subjected to statistical and geostatistical analyses. The nature of the clay minerals and magnetic susceptibility was dependent on the variation of the soil parent material. High values of magnetic susceptibility were associated with the presence of maghemite and magnetite of coarse size. The spatial variability of crystallinity and the content of Fe oxides, as well as magnetic susceptibility, were dependent on the age of the geomorphic surfaces. The youngest surface had greater spatial variability of these attributes. The iron (goethite and hematite) and aluminum (gibbsite) oxides in the youngest geomorphic surface influenced the low values of soil density and high values of total pore volume, micropores and $\mathrm{P}$ adsorption. The characterization of the spatial variability of Fe oxides and susceptibility allowed for the delineation of homogeneous areas.

Keywords: goethite, hematite, gibbsite, kaolinite, soil mapping

\section{Introduction}

Humid tropical regions have areas of global concern about food production, even though there are extremely competitive areas for grain and fuel such as in the Midwest and Southeast of Brazil. Due to soil diversity, soil characterization is necessary, based on a system that takes into account the soil genesis. In this study, we characterized the clay mineralogy of highly weathered soils and their relationship with the landscape feature, aiming to present the potential of this tool to help delineate mapping units.

Tropical soils in humid areas and old geomorphic surfaces have highly weathered clay minerals with a predominance of $1: 1$ clay minerals, $\mathrm{Fe}, \mathrm{Al}$ oxides and hydroxides (denominated in this study as oxides). Furthermore, these soils, also known as laterite, have an unquestionable importance to agronomy and civil engineering, because these soils respond to cement stabilization and, in some cases, lime stabilization (Townsend, 1985). Associations between goethite and hematite are the most common $\mathrm{Fe}$ oxides in weathered soils from tropical and subtropical regions (Schwertmann and Taylor, 1989). Several relationships between $\mathrm{Fe}$ and $\mathrm{Al}$ oxides and physical and chemical properties in the soil are reported in the literature (McNeal et al., 1968; Curi and Franzmeier, 1984; Schwertmann and Kämpf, 1985; Borggaard et al., 2004; Mesquita Filho and Torrent, 1993; Schaefer et al., 2004; Camargo et al., 2013).

Camargo et al. (2008a) found that the spatial dependence of crystallinity of $\mathrm{Fe}$ and $\mathrm{Al}$ oxides and kaolinite is relied to landscape compartments in an Oxisol originated from basalt, enabling the delineation of areas based on soil-landscape models in detailed scales. The influence of Fe oxides and their crystallinity in aggregates (Camargo et al., 2008b) as well as in P spatial availability (Camargo et al., 2013) within the compartments was also observed, showing that the delimitation of Fe oxides allow for specific soil management.

Further studies would help in optimizing and recognizing the degree of homogeneity of mapping units, based on the characterization of Fe oxides and magnetic susceptibility (MS). Therefore, this study aimed to evaluate the spatial variability of clay minerals, MS, $\mathrm{P}$ adsorbed and physical attributes in Oxisols of sandstones of the Bauru Group in different geomorphic surfaces.

\section{Materials and Methods}

\section{Sampling system}

The area studied is located in the northeast of São Paulo State, Brazil, in the municipality of Guariba (21 $24^{\prime} 17^{\prime \prime} \mathrm{S} ; 48^{\circ} 09^{\prime} 46^{\prime \prime} \mathrm{W}$; average altitude $640 \mathrm{~m}$. The climate is mesothermal with dry winters (Cwa) (Köppen classification) with average precipitation of 1,400 $\mathrm{mm}$, concentrated between Nov and Feb. The natural vegetation consists of tropical semideciduous forest and the soils are cropped with sugarcane plantations with a mechanical harvesting system.

The geomorphic surfaces (GS) were identified and mapped using topographic and stratigraphic criteria, 
based on visual observations of unevenness or breaks in the relief shape, as recommended by Ruhe (1969) and Daniels et al. (1971). Three GS's were identified (I, II and III). GS I is approximately 400-m long with a slope ranging from 0 to $4 \%$. It is considered the oldest surface of the study area with a depositional characteristic. The boundary between GS II and III is approximately at $1,500 \mathrm{~m}$ at the top. GS II and III are considered erosional and GS II has the shape of a gentle slope plan. The GS III has a characteristically steeper slope $(7 \%)$. Older GS are more stable, usually found in water dividers and, are, thus, depositional environments, since they have gentle slopes. Younger GS, on the other hand, are more variable and occurs in erosional environments (Graham et al., 1990; Phillips, 2004).

To evaluate the spatial variability of the attributes studied, soil samples were collected along a transect where the GS were identified. The direction of the transect was selected from the high topography following the lower elevations. Soil samples were collected every $25 \mathrm{~m}$ (at a depth of 0.0 to $0.2 \mathrm{~m}$ ). We collected 40 samples near the transect in each GS to support the spatial variability analysis. The strip of land which is the transect as well as the points of sample collection of geomorphic surfaces near the transect measures 145 ha (Figure 1).

We delimited and georeferenced an area of 500 ha where the transect occupied a central position. A soil sample was collected every 6 ha at a depth of 0.0 to 0.2 $\mathrm{m}$, totaling 88 samples. These samples were added to those collected from the transect and its side (Figure 1). The soil was classified (Soil Survey Staff, 1999) as Typic Hapludox in GS I, Typic Eutrudox and Typic Hapludox in GS II and Typic Eutrudox in GS III (Table 1). The parent material in the study area is Cretaceous sandstones of Adamantina Formation.

\section{Physical analyses}

The particle size analysis was performed using a 0.1 $\mathrm{M} \mathrm{NaOH}$ solution as a dispersant in a low-speed stirring apparatus (Day, 1965). The clay was determined using a pipette, the fine and coarse sands were separated by
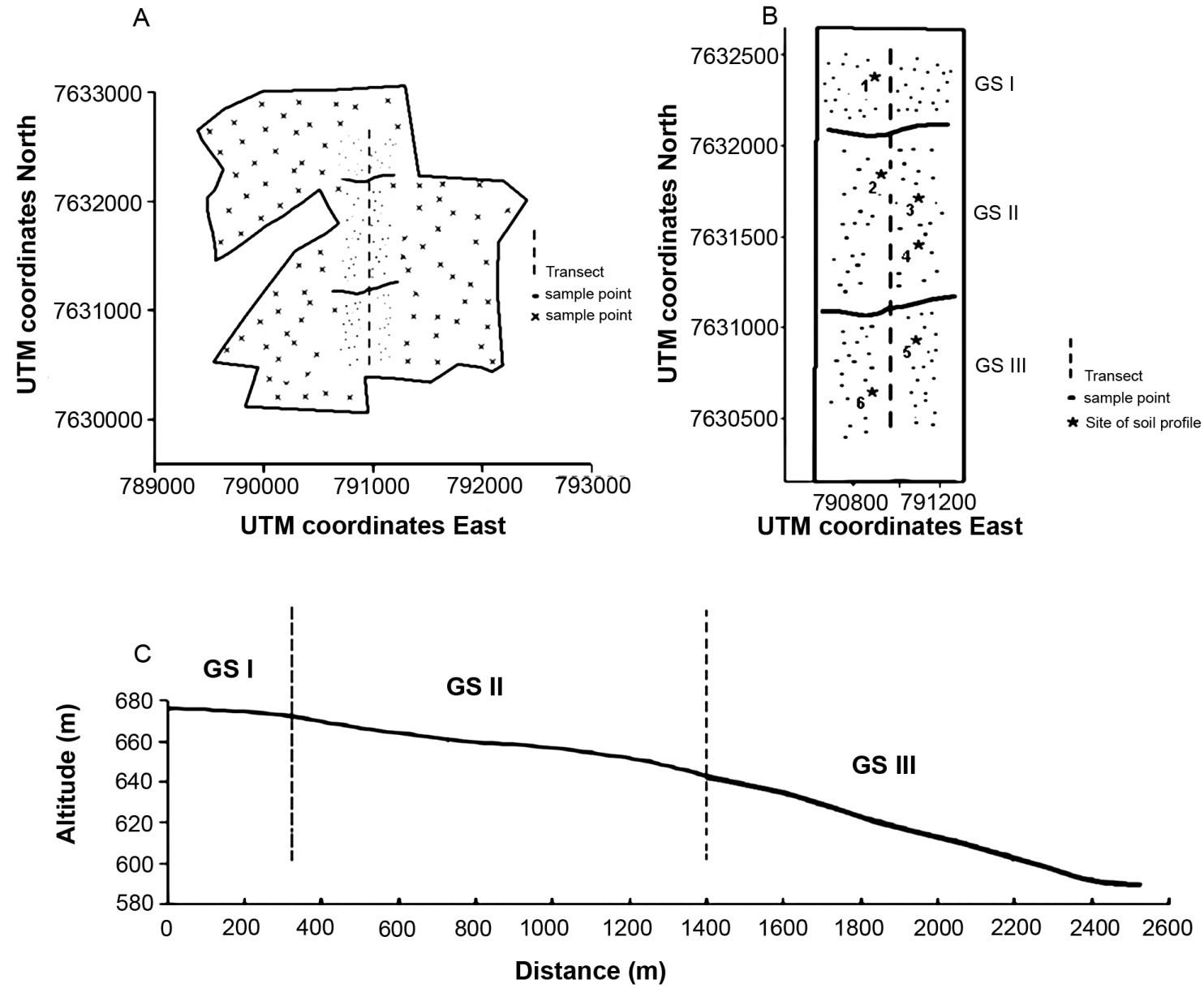

Figure 1 - Study area. A) Area of 500 hectares around the transect; B) area occupied by transect and its side (145 hectares); C) elevation profile of the transect. GS = geomorphic surfaces. Profiles 1, 2 and 3 = Typic Hapludox; 4, 5 and 6 = Typic Eutrudox. 
Table 1 - Chemical and physical characteristics of the profiles by geomorphic surface.

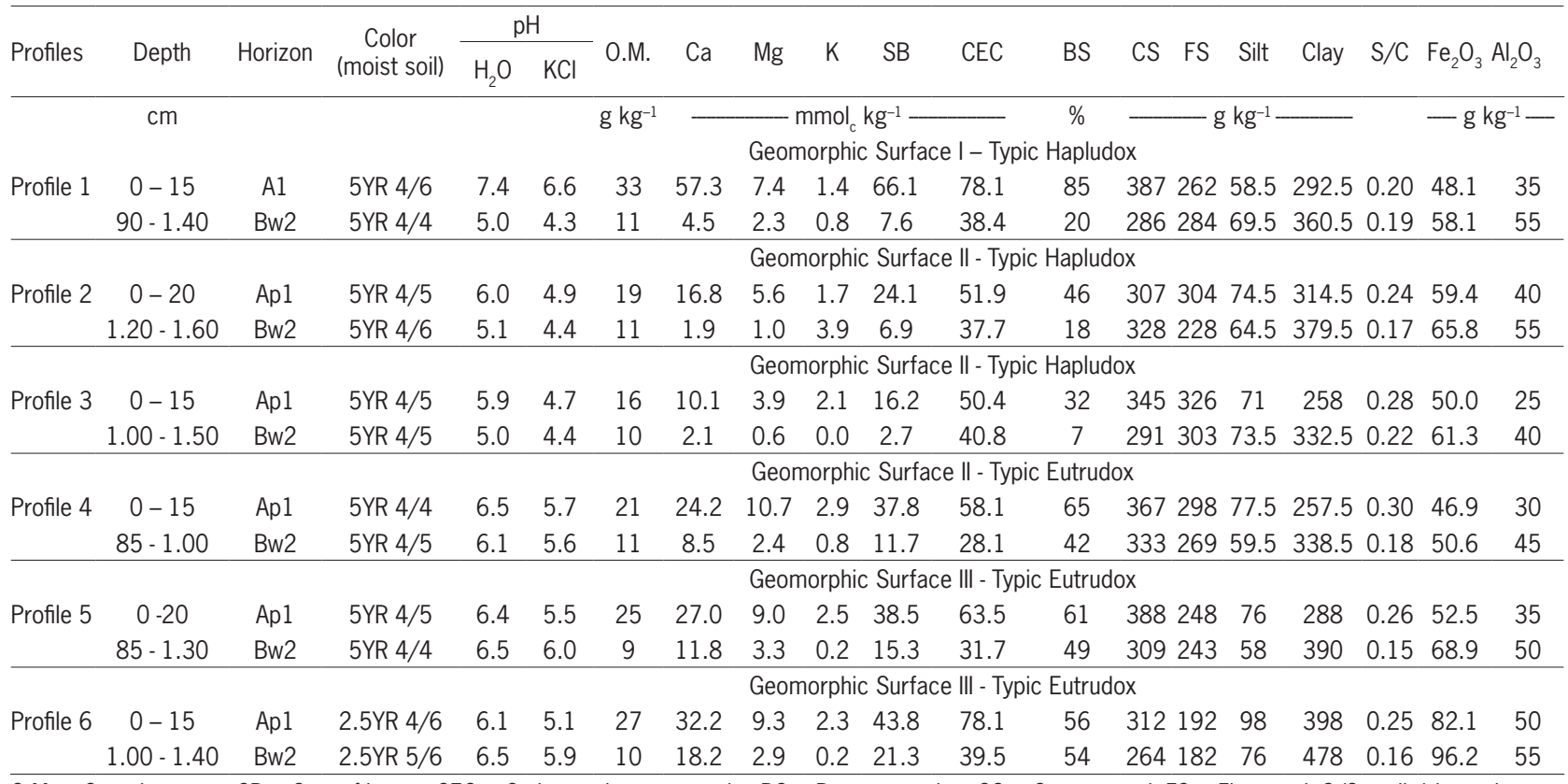

O.M. = Organic matter, $\mathrm{SB}=$ Sum of bases, $\mathrm{CEC}=$ Cation exchange capacity, $\mathrm{BS}=$ Base saturation, $\mathrm{CS}=$ Coarse sand, $\mathrm{FS}=$ Fine sand, $\mathrm{S} / \mathrm{C}=$ silt $/ \mathrm{clay}$ ratio.

sieving and silt was calculated by difference. Undisturbed samples were collected to determine soil porosity (porosity, macropores and micropores). The samples were saturated for $48 \mathrm{~h}$ in a tray with water up to $2 / 3$ of the ring height. After saturation, the samples were drained to the potential equivalent to $-0.006 \mathrm{MPa}$, using a tension table and bulk density was determined by the known volume method (Grossman and Reinsch, 2002)). These analyses were performed on samples collected in the 145 ha area.

\section{Mineralogical analyses}

Clay mineralogy was determined by x-ray diffraction (XRD). The analyses were conducted in non oriented slides. The clay was separated by centrifugation according to the Jackson method (1985). The characterization of hematite $(\mathrm{Hm})$ and goethite (Gt) was performed after treating the clay fraction with 5 $\mathrm{M} \mathrm{NaOH}$ (1g clay $100 \mathrm{~mL}^{-1}$ solution), according to the Norrish and Taylor method (1961) with modification by Kämpf and Schwertmann (1982). The ratio Gt/ $(\mathrm{Gt}+\mathrm{Hm})$ was obtained after calculating the reflection areas of Hm (012) and Gt (110). The peak area of Gt (110) was multiplied by 0.35 , due to the intensity of 35 $\%$ of Hm (012) (Kämpf and Schwertmann, 1998). The mean crystallite dimension (MCD) was calculated from the width at half height (WHH) reflection minerals $\mathrm{Hm}$ (110 and 012) and Gt (110 and 111) using the Scherrer equation (Klug and Alexander, 1974).

For kaolinite (Kt) and gibbsite (Gb) characterization, Fe oxides were removed from the clay fraction using the dithionite-citrate-bicarbonate method (DCB) according to Mehra and Jackson (1960), and screened through a 0.10-mm mesh. The ratio $\mathrm{Kt} /(\mathrm{Kt}+\mathrm{Gb})$ was calculated using the reflection areas of the $\mathrm{Kt}(001)$ and $\mathrm{Gb}$ (002) of the XRD patterns. The MCD of Gb and Kt was calculated from the WHH mineral reflexes $\mathrm{Kt}(001)$ and $\mathrm{Gb}(002)$ using the Scherrer equation (Klug and Alexander, 1974).

The diffractometer used was the Mini-Flex Rigaku-II, using a cathode copper with a nickel filter and $\mathrm{k} \alpha$ radiation $(20 \mathrm{~mA}, 30 \mathrm{kV})$. The scan speed used was $1^{\circ} 2 \theta$ /minute amplitude $23-49{ }^{\circ} 2 \theta$ for the $\mathrm{Hm}$ and Gt characterization, and from 11 to $19{ }^{\circ} 2 \theta$ for the Kt and $\mathrm{Gb}$ characterization.

The Al substitution (AS) in Gt was used in the equation proposed by Schulze (1984):

molAl $\%=1730-572 . \mathrm{c}$

where $\mathrm{c}=1 /(1 / \mathrm{d} 1112-1 / \mathrm{D} 1102) 1 / 2$.

To calculate the AS content in $\mathrm{Hm}$, we used the equation proposed by Schwertmann et al. (1979):

molAl $\%=3098.8$ to $615.1 \times$ a0

where $\mathrm{a} 0=2 \times \mathrm{d} 110$.

The Fe content for the entire pedogenic Fe oxide extracted by dithionite-citrate-bicarbonate (Fed), was performed according to Mehra and Jackson (1960). The Fe content extracted by ammonium oxalate (Feo) was related to pedogenic $\mathrm{Fe}$ oxides of low crystallinity (Schwertmann, 1964).

To calculate the Gt content, the crystalline $\mathrm{Fe}$ content was multiplied by the ratio $\mathrm{Gt} /(\mathrm{Gt}+\mathrm{Hm})$ and by 1.59. For the Hm content, the crystalline Fe content was 
multiplied by 1.43 after the Fe content corresponding to Gt had been subtracted from this value, according to the equations:

$[(\mathrm{Gt} / \mathrm{Gt}+\mathrm{Hm})] \times(\mathrm{Fed} \%-\mathrm{Feo} \%)=\% \mathrm{FeG}$

$\mathrm{FeGt} \% \times 1.59=\mathrm{FeOOH}=\% \mathrm{Gt}$

FeGt\% $-($ Fed\%-Feo\% $)=$ FeHm\%

$\mathrm{FeHm} \% \times 1.43=\mathrm{Fe}_{2} \mathrm{O}_{3}=\mathrm{Hm} \%$

\section{Magnetic Susceptibility (MS)}

MS was measured in a diffuse reflectance spectrometer coupled to an MS2B laboratory sensor of two frequencies. This sensor allowed the MS to be measured using a low and alternating magnetic field at an intensity of $80 \mathrm{~A} \mathrm{~m}^{-1}\left(10^{-4} \mathrm{~T}\right)$ of varying frequency.

\section{Phosphorus adsorption}

$\mathrm{P}$ adsorption was assessed in accordance with the methodology of Fassbender and Igue (1967) using samples consisting of $2.0 \mathrm{~g}$ of air dried soil transferred to $50 \mathrm{ml}$ centrifuge tube. $20 \mathrm{~mL}$ of a $0.005 \mathrm{M} \mathrm{KH}_{2} \mathrm{PO}_{4}$ solution containing $\mathrm{CaCl}_{2}$ were added at a $\mathrm{P}$ concentration of $100 \mathrm{mg} \mathrm{L}^{-1}$. The soil:solution ratio was 1:10. Samples containing phosphate solutions were stirred for $16 \mathrm{~h}$ at constant temperature. After stirring, centrifugation was performed at 2,500 rpm for $15 \mathrm{~min}$. The supernatant was collected to determine the $\mathrm{P}$ concentration in equilibrium by means of a molecular absorption spectrophotometer. To determine $\mathrm{P}$ in the spectrophotometer, we transferred the supernatant to $1 \mathrm{ml}$ aliquot in the test tube, adding $50 \mathrm{~mL}$ of a sulfomolybdic acid solution and three similar solutions of $200 \mathrm{~g} \mathrm{~L}^{-1}$ of ascorbic acid. This solution was stirred individually for $30 \mathrm{~s}$ and left to rest for $15 \mathrm{~min}$. The spectrophotometer wavelength was selected for $650 \mathrm{~nm}$, which corresponds to the maximum absorption peak of the complex formed. The amount of $\mathrm{P}$ adsorbed $\left(\mathrm{P}_{\text {ads }}\right)$ by the soil was calculated by subtracting the value determined in solution from the total amount added. This analysis was performed in the samples collected from the 145 ha area.

\section{Treatment of selective dissolution of maghemite}

The treatment of maghemite selective dissolution was applied in accordance with the methodology proposed by Schwertmann and Fechter (1984), which consists of treating $1 \mathrm{~g}$ air-dried soil with $40 \mathrm{ml}$ of $1.8 \mathrm{M} \mathrm{H}_{2} \mathrm{SO}_{4} 75$ $80{ }^{\circ} \mathrm{C}$ for $2 \mathrm{~h}$ and eliminating part of the $\mathrm{Hm}$ and/or Gt existing in the samples. Therefore, we carried out a test with two samples of each GS changing the exposure time (from 45 min to $2 \mathrm{~h}$ ) and the $\mathrm{H}_{2} \mathrm{SO}_{4}$ concentration $(0.8$ to $1.8 \mathrm{M}$ ) to determine the most suitable conditions. The results of the test showed that the best time was $1.2 \mathrm{~h}$ and best concentration of $\mathrm{H}_{2} \mathrm{SO}_{4}$ was $1.3 \mathrm{M}$ (unpublished data). The Fe content extracted by $\mathrm{H}_{2} \mathrm{SO}_{4}$ was determined colorimetrically using a spectrophotometer following the method described by Olson and Ellis (1982). The waste dissolution was subjected to MS analysis after washing with deionized water and dried.

\section{Statistical and geostatistical analyses}

The variability of soil attributes was evaluated by exploratory data analysis, calculating the mean, median, coefficient of variation and the coefficient of skewness and kurtosis. The mean difference between the GS was tested by Tukey test. The analysis of spatial dependence of data was performed by geostatistics (Matheron, 1963; Isaaks and Srivastava, 1989; Vieira et al., 1983) using semivariograms. To determine spatial dependence, we used GS + software, and to model and set the semivariogram, the models considered were spherical, exponential and gaussian (McBratney and Webster, 1983).

\section{Results and Discussion}

Higher clay and silt contents and smaller sand contents were found in the GS III area (Table 2). This can be explained by a variation of the sandstone strata, sandy on top, with increasing clay content at the lower elevations. The sandstones of Adamantina Formation (Bauru Group) have fine granulation, usually with cross bedding, alternating with clay-rich materials such as mudstones. In the site studied, the higher clay content and the higher $\mathrm{Fe}_{2} \mathrm{O}_{3}$ levels (Table 1), indicate that the GS III is a region under the influence of mudstones, which are characterized by a higher concentration of clay. Soils affected by mudstones have peculiarities that affect their physical and chemical attributes and, therefore, should be studied in order to implement the appropriate management procedures.

The crystallinity of Gt (111) was different for GS III from the other surfaces ( $p<0.05)$. In GS III, Gt (111) had the highest degree of crystallinity, corroborated by high MCD values. The opposite occurred with the $\mathrm{Hm}$ mineral, which was different from WHH (with the exception of $\mathrm{Hm}(012))$ and from MCD between GS I and the other surfaces $(p<0.05)$. The Hm presented a lower degree of crystallinity in GS I and II (Table 3).

The AS in Gt and Hm had the highest values where the crystals showed a lower degree of crystallinity (Table 4). This is attributed to the isomorphic substitution of $\mathrm{Fe}$ by $\mathrm{Al}$ in the crystal structure, causing a contraction of the unit cell, thus decreasing the size of the crystals in these oxides, lowering the degree of crystallinity Norrish and Taylor, 1961).

The Gt and Hm contents were higher $(p<0.05)$ in GS III in relation to the other surfaces. In all GSs, Hm contents are greater than Gt contents; however, there was a greater ratio $\mathrm{Gt} /(\mathrm{Gt}+\mathrm{Hm}$ ) in GS I and II (Table 4) though the difference in GS III was less pronounced. This result was consistent with the more yellowish color of the soil in GS I and II (Table 1). Higher levels of Fed and Feo were found in GS III, which is consistent with the higher $\mathrm{Fe}_{2} \mathrm{O}_{3}$ values in this surface, thus confirming the variability in the parent material. 
Table 2 - Descriptive statistics of the texture attributes in the area of 145 ha.

\begin{tabular}{|c|c|c|c|c|c|c|c|c|c|c|}
\hline & GS & Mean & Median & Var. & Max. & Min. & Skewness & Kurtosis & $S D^{(1)}$ & $\mathrm{CV}^{(2)}$ \\
\hline & 1 & $336.07 \mathrm{~b}$ & 336 & 282.73 & 377 & 302 & 0.18 & -0.05 & 16.8 & 5.0 \\
\hline \multirow[t]{3}{*}{ Clay ${ }^{(3)}$} & $\|$ & $317.05 b$ & 317 & 1283.26 & 434 & 204 & -0.06 & 1.00 & 35.8 & 11.3 \\
\hline & III & $426.48 \mathrm{a}$ & 411 & 6431.94 & 607 & 196 & 0.28 & -0.06 & 80.2 & 18.8 \\
\hline & 1 & $611.30 \mathrm{~b}$ & 614 & 297.79 & 647 & 553 & -0.85 & 2.24 & 17.3 & 2.8 \\
\hline \multirow[t]{3}{*}{$\mathrm{TS}^{(3)}$} & $\|$ & $643.14 \mathrm{a}$ & 646 & 1560.97 & 762 & 482 & -0.54 & 2.23 & 39.5 & 6.1 \\
\hline & III & $508.0 \mathrm{c}$ & 538 & 11798.10 & 746 & 261 & -0.71 & -0.33 & 108.6 & 21.4 \\
\hline & 1 & $52.63 \mathrm{c}$ & 49 & 340.81 & 121 & 28 & 1.43 & 3.31 & 18.5 & 35.1 \\
\hline \multirow[t]{2}{*}{ Silt(3) } & $\|$ & $39.81 \mathrm{~b}$ & 38 & 192.52 & 84 & 16 & 0.76 & 0.62 & 13.9 & 34.8 \\
\hline & III & $65.56 \mathrm{a}$ & 54 & 1229.51 & 148 & 19 & 0.94 & -0.20 & 35.1 & 53.5 \\
\hline
\end{tabular}

(1) Standard deviation; (2)Coefficient of variation (\%); ${ }^{(3)} \mathrm{g} \mathrm{kg}^{-1}$. GS= geomorphic surface; Var. = Variance; Max. = Maximum; Min. = Minimum; TS = Total Sand. Values in a column followed by the same letter were not different (Tukey test, $p<0.05$ ).

Table 3 - Descriptive statistics of Width at Half Height [WHH ( $\left.\left.{ }^{\circ} 2 \theta\right)\right]$ and of Mean Crystallite Dimension [MCD (nm)] of Fe oxides, area of 145 ha at 0.0 to $0.2 \mathrm{~m}$

\begin{tabular}{|c|c|c|c|c|c|c|c|c|c|c|}
\hline & GS & Mean & Median & Min & Max. & Var. & Skewness & Kurtosis & $S D^{(1)}$ & $\mathrm{CV}^{(2)}$ \\
\hline \multirow{3}{*}{$\mathrm{WHH}_{\mathrm{gt110}}$} & 1 & $0.310 \mathrm{a}$ & 0.310 & 0.180 & 0.670 & $6 \mathrm{E}-03$ & 2.41 & 10.66 & 0.08 & 25.99 \\
\hline & $\|$ & $0.337 \mathrm{a}$ & 0.330 & 0.140 & 0.650 & $5 \mathrm{E}-03$ & 0.76 & 3.52 & 0.07 & 22.31 \\
\hline & III & $0.356 \mathrm{a}$ & 0.340 & 0.110 & 0.690 & 0.02 & 0.19 & -0.93 & 0.14 & 40.17 \\
\hline \multirow{3}{*}{$\mathrm{WHH}_{\mathrm{gt111}}$} & I & $0.601 \mathrm{a}$ & 0.610 & 0.180 & 0.900 & $36 \mathrm{E}-03$ & -0.420 & -0.38 & 0.19 & 31.72 \\
\hline & $\|$ & $0.598 \mathrm{a}$ & 0.590 & 0.170 & 0.980 & 33E-03 & -0.074 & -0.43 & 0.18 & 30.54 \\
\hline & III & $0.366 \mathrm{~b}$ & 0.320 & 0.110 & 0.880 & $35 \mathrm{E}-03$ & 1.23 & 1.01 & 0.19 & 51.64 \\
\hline \multirow{3}{*}{$\mathrm{WHH}_{\mathrm{hm} 110}$} & I & $0.161 \mathrm{~b}$ & 0.150 & 0.070 & 0.360 & $2 \mathrm{E}-03$ & 1.81 & 6.04 & 0.05 & 31.30 \\
\hline & $\|$ & $0.185 \mathrm{a}$ & 0.190 & 0.020 & 0.320 & $2 \mathrm{E}-03$ & -0.31 & 1.10 & 0.04 & 26.88 \\
\hline & III & $0.183 \mathrm{a}$ & 0.180 & 0.01 & 0.380 & $2 \mathrm{E}-03$ & 0.12 & 5.48 & 0.04 & 25.84 \\
\hline \multirow{3}{*}{$\mathrm{WHH}_{\mathrm{hm} 012}$} & I & $0.255 b$ & 0.200 & 0.140 & 0.560 & 9E-03 & 2.39 & 5.63 & 0.09 & 44.22 \\
\hline & $\|$ & $0.243 b$ & 0.240 & 0.120 & 0.540 & $3 \mathrm{E}-03$ & 1.67 & 6.37 & 0.06 & 25.66 \\
\hline & III & $0.263 \mathrm{a}$ & 0.270 & 0.180 & 0.480 & 2E-03 & 0.95 & 1.93 & 0.53 & 20.60 \\
\hline \multirow{3}{*}{$\mathrm{MCD}_{\mathrm{gt110}}$} & I & $28.81 \mathrm{a}$ & 27.41 & 12.66 & 47.28 & 41.46 & 0.63 & 1.77 & 6.43 & 22.35 \\
\hline & $\|$ & $26.04 \mathrm{a}$ & 25.73 & 13.10 & 52.68 & 33.52 & 1.51 & 5.47 & 5.79 & 26.15 \\
\hline & |II & $28.76 \mathrm{a}$ & 24.78 & 12.28 & 76.00 & 197.25 & 1.26 & 1.21 & 14.04 & 48.83 \\
\hline \multirow{3}{*}{$\mathrm{MCD}_{\mathrm{gt111}}$} & I & $16.32 \mathrm{~b}$ & 14.04 & 9.42 & 48.93 & 73.54 & 5.45 & 6.42 & 8.57 & 52.40 \\
\hline & $\|$ & $15.92 b$ & 14.25 & 8.55 & 49.70 & 48.54 & 2.33 & 7.25 & 6.96 & 43.76 \\
\hline & III & $28.55 \mathrm{a}$ & 27.11 & 9.50 & 56.76 & 157.65 & 0.53 & -0.53 & 12.55 & 43.97 \\
\hline \multirow{3}{*}{$M C D_{h m 110}$} & I & $57.83 \mathrm{a}$ & 56.97 & 24.65 & 91.48 & 214.09 & 0.32 & 0.69 & 14.63 & 25.30 \\
\hline & $\|$ & $49.12 b$ & 47.16 & 27.73 & 91.41 & 151.24 & 0.98 & 1.11 & 12.29 & 25.04 \\
\hline & III & $48.01 \mathrm{~b}$ & 48.69 & 22.05 & 74.40 & 79.16 & 0.06 & 0.69 & 8.89 & 18.53 \\
\hline \multirow{3}{*}{$\mathrm{MCD}_{\mathrm{hm} 012}$} & I & $66.47 \mathrm{a}$ & 65.60 & 22.37 & 108 & 333.02 & -0.13 & 0.614 & 18.24 & 27.45 \\
\hline & $\|$ & $57.43 b$ & 55.76 & 20.50 & 102.55 & 208.00 & 0.50 & 1.16 & 14.42 & 25.15 \\
\hline & III & $51.13 b$ & 50.23 & 21.32 & 73.80 & 114.90 & 0.033 & -0.21 & 10.71 & 20.96 \\
\hline
\end{tabular}

(1) Standard deviation; ${ }^{(2)}$ Coefficient of variation (\%). GS = geomorphic surface; Min. = Minimum; Max. = Maximum; Var. = Variance; Hm = Hematite, Gt = Goethite. Values in a column followed by the same letter were not different (Tukey test, $p<0.05$ ).

Soils at the landscape summit tend to have less water content and higher temperatures /Curi and Franzmeier, 1984), favoring the dehydration step of the ferrihydrite to Hm (Torrent et al., 1982; Kampf and Schwertmann, 1983). In GS I, the $\mathrm{pH}$ was around 7.4 at the depth sampled for the mineral study (Table 1). A $\mathrm{pH}$ near neutrality favors ferrihydrite aggregation and, thereby, the Hm formation (Schwertmann and Murad, 1983). This is consistent with a higher degree of crystallinity of $\mathrm{Hm}$ in soils that occur in GS I, which is older and more stable.

In GS III, the source material may provide higher $\mathrm{Fe}$ content for $\mathrm{Hm}$ formation but with a lower degree of crystallinity. However, in this GS, conditions were favorable for increasing the degree of crystallinity of Gt. Organic matter (OM) and Gt formation over $\mathrm{Hm}$ (Schwertmann and Taylor, 1989). The role of OM consists of complexing $\mathrm{Fe}$, inhibiting the formation of ferrihydrite, which is an obligatory Hm precursor (Curi and Franzmeier, 1984). However, in this study, the influence of organic matter may be affecting the degree of crystallinity of the mineral, not its content.

In addition to geochemical processes, the position of soils in the landscape affects the crystallinity of Fe oxides (Curi and Franzmeier, 1984). These authors found Gt with a lower degree of crystallinity in the 
Table 4 - Descriptive statistics of Al substitution (AS), contents of Fe oxides and magnetic susceptibility (MS) of the area of 145 ha, at 0.0 to $0.2 \mathrm{~m}$.

\begin{tabular}{|c|c|c|c|c|c|c|c|c|c|c|}
\hline & GS & Mean & Median & Min & Max. & Var. & Skewness & Kurtosis & $S D^{(1)}$ & $\mathrm{CV}^{(2)}$ \\
\hline & 1 & $5.77 b$ & 5.5 & 1 & 15 & 17.20 & 0.67 & -0.35 & 4.14 & 74.69 \\
\hline \multirow[t]{3}{*}{ ASHm } & $\|$ & $7.63 \mathrm{a}$ & 7.0 & 1 & 16 & 15.23 & 0.46 & -0.07 & 3.9 & 51.14 \\
\hline & III & $8.74 \mathrm{a}$ & 9 & 1 & 16 & 15.25 & -0.02 & -0.65 & 3.9 & 44.67 \\
\hline & 1 & $27.33 \mathrm{a}$ & 28 & 13 & 36 & 28.47 & -0.70 & 0.22 & 5.33 & 19.55 \\
\hline \multirow[t]{3}{*}{ ASGt } & $\|$ & $27.41 \mathrm{a}$ & 29 & 9 & 36 & 45.19 & -0.83 & -0.12 & 6.72 & 24.52 \\
\hline & III & $17.37 b$ & 17 & 4 & 35 & 50.44 & 0.55 & 0.06 & 7.10 & 40.87 \\
\hline & 1 & $0.29 a$ & 0.30 & 0.17 & 0.40 & $1 \mathrm{E}-03$ & -0.15 & 0.13 & 0.04 & 16.63 \\
\hline \multirow[t]{3}{*}{$\mathrm{Gt} /(\mathrm{Gt}+\mathrm{Hm})$} & $\|$ & $0.32 \mathrm{a}$ & 0.33 & 0.11 & 0.56 & $75 E-03$ & -0.02 & 0.017 & 0.08 & 27.01 \\
\hline & III & $0.21 b$ & 0.20 & 0.07 & 0.57 & 96 E-03 & 1.57 & 3.42 & 0.09 & 45.93 \\
\hline & 1 & $20.4 \mathrm{~b}$ & 19.7 & 9.6 & 37.5 & 30.25 & 0.75 & 1.57 & 5.5 & 27.01 \\
\hline \multirow[t]{3}{*}{$\mathrm{Gt}^{(3)}$} & $\|$ & $19.7 \mathrm{~b}$ & 19.1 & 7.9 & 41.0 & 35.29 & 1.24 & 2.92 & 5.9 & 30.14 \\
\hline & III & $38.4 \mathrm{a}$ & 41.4 & 6.5 & 86.2 & 396.35 & 0.23 & -0.30 & 19.91 & 51.85 \\
\hline & 1 & $34.1 \mathrm{~b}$ & 35.5 & 19.1 & 53.6 & 32.78 & 0.51 & 3.91 & 5.72 & 16.77 \\
\hline \multirow[t]{3}{*}{$\mathrm{Hm}^{(3)}$} & $\|$ & $31.9 b$ & 31.0 & 15.3 & 58.6 & 66.12 & 0.82 & 1.80 & 8.13 & 25.51 \\
\hline & III & $65.5 \mathrm{a}$ & 61.4 & 9.3 & 123.30 & 400.95 & 0.51 & 1.69 & 20.02 & 30.55 \\
\hline & I & $39.3 b$ & 40.0 & 26.9 & 44.6 & 14.10 & -1.19 & 1.95 & 3.75 & 9.55 \\
\hline \multirow[t]{3}{*}{$\mathrm{Fed}^{(3)}$} & $\|$ & $39.7 \mathrm{~b}$ & 38.6 & 24.8 & 69.9 & 67.00 & 1.51 & 3.50 & 0.81 & 20.60 \\
\hline & III & $64.4 \mathrm{a}$ & 60.4 & 18.6 & 109.9 & 318.78 & 0.56 & 0.05 & 17.85 & 27.71 \\
\hline & 1 & $5.3 b$ & 5.5 & 2.2 & 7.3 & 1.27 & -0.87 & 1.18 & 1.12 & 21.00 \\
\hline \multirow[t]{3}{*}{$\mathrm{Feo}^{(3)}$} & $\|$ & $5.3 b$ & 5.3 & 2.6 & 9.1 & 1.14 & 0.70 & 1.74 & 1.06 & 20.04 \\
\hline & III & $6.8 \mathrm{a}$ & 6.8 & 3.2 & 10.8 & 2.68 & 0.17 & -0.39 & 1.63 & 24.03 \\
\hline & I & $0.203 b$ & 0.192 & 0.175 & 0.363 & $1 \mathrm{E}-03$ & 3.59 & 15.81 & 0.03 & 16.19 \\
\hline \multirow[t]{2}{*}{$M S^{(4)}$} & $\|$ & $0.281 b$ & 0.240 & 0.128 & 0.630 & 0.01 & 1.13 & 0.75 & 0.11 & 41.89 \\
\hline & III & $1.046 \mathrm{a}$ & 0.770 & 0.148 & 2.91 & 0.37 & 1.36 & 1.03 & 0.61 & 58.58 \\
\hline
\end{tabular}

(1) Standard deviation; (2)Coefficient of variation (\%); ${ }^{(3)} \mathrm{g} \mathrm{kg}^{-1} ;{ }^{(4)} 10^{-8} \mathrm{~m}^{3} \mathrm{~kg}^{-1}$. GS= geomorphic surface; Min. = Minimum; Max. = Maximum; Var. = Variance; Hm = Hematite; Gt = Goethite; Fed = iron oxides extracted by dithionite-citrate-bicarbonate; Feo = iron extracted by ammonium oxalate; $\mathrm{Hm}=\mathrm{Hematite}, \mathrm{Gt}=\mathrm{Goethite}$. Values in a column followed by the same letter were not different (Tukey test, $p<0.05$ ).

lower landscape, which disagrees with the current study. However, the source material in the study site used by Curi and Franzmeier (1984) was the product of changes in the basaltic rocks. These results indicate that the variation of the source material indicates that generalizations about the formation of $\mathrm{Fe}$ oxides in the soil-landscape relationships should be approached with caution.

The MS was also higher in GS III, which is consistent with the higher clay and $\mathrm{Fe}$ oxide contents in the soil surface. The mineralogical origin of MS in soils with low levels of ferrimagnetic minerals cannot be identified by using only the XRD technique. The magnetic behavior is more evident in soils with greater clay fraction (Fontes et al., 1996). In the sand fraction, magnetite is oxidized directly in $\mathrm{Hm}$, while in the clay fraction magnetite is oxidized in maghemite (Singer et al., 1995). The soils used in this study were sandstone and the MS values were, on average, relatively lower than in maghemite soils $\left(2.86\right.$ to $\left.4.40 \times 10^{-8} \mathrm{~m}^{3} \mathrm{~kg}^{-1}\right)$ (Thompson and Oldfield, 1986). However, the highest MS value $\left(2.91 \times 10^{-8} \mathrm{~m}^{3} \mathrm{~kg}^{-1}\right)$ in GS III shows the need for further studies to investigate the presence of ferrimagnetic minerals in these soils.

At $1.2 \mathrm{~h}$ of exposure to $\mathrm{H}_{2} \mathrm{SO}_{4}(1.3 \mathrm{M})$, the $\mathrm{MS}$ in the residues decreased drastically and remained constant at low values, except for GS III (Figure 2A), but the Fe content extracted (Figure 2B) continued to increase in time. These results confirm that MS was affected by the presence of maghemite that had dissolved in the soil after $1.2 \mathrm{~h}$, because the iron content extracted increased thereafter due to the dissolution of other $\mathrm{Fe}$ oxides such as $\mathrm{Hm}$ and $\mathrm{Gt}$.

Costa et al. (1999) found that for soils with a high content of $\mathrm{Fe}$ oxides $\left(\mathrm{Fe}_{2} \mathrm{O}_{3}\right.$ content higher than $180 \mathrm{~g} \mathrm{~kg}^{-1}$ ) the period of exposure to $\mathrm{H}_{2} \mathrm{SO}_{4}(1.8 \mathrm{M})$ for maghemite dissolution was $2 \mathrm{~h}$. The difference in relation to this study may be attributed to intermediate content of Fe oxides in the soil compared to the works cited and consequently with intermediate maghemite contents. These results indicate that the period of exposure to $\mathrm{H}_{2} \mathrm{SO}_{4}$ should take into account the Fe oxide content in each soil.

The MS measures in GS III remained constant at high values after successive Fe extractions with $\mathrm{H}_{2} \mathrm{SO}_{4}$ over several exposure periods (Figure 2A). This result can be attributed to the presence of magnetite from the rock with very small size in addition to goethite, hematite and maghemite, since soils originating from this parent material may contain its traces. Moreover, magnetite of coarse size is not dissolved by $\mathrm{H}_{2} \mathrm{SO}_{4}$, which may have affected the measurements. 

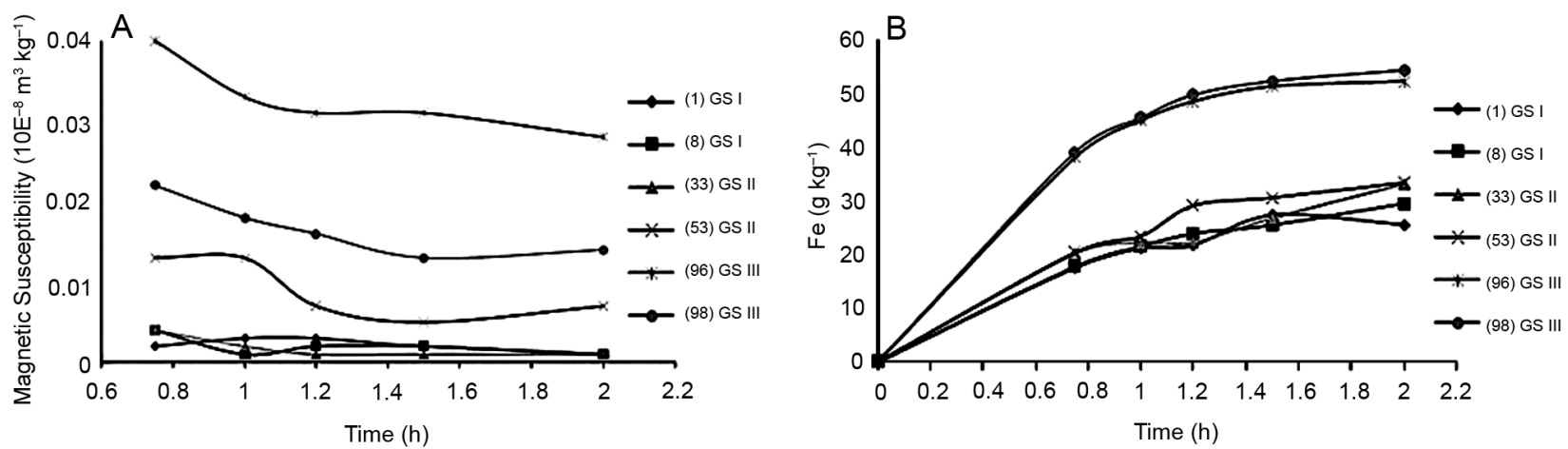

Figure 2 - A) Magnetic susceptibility of the sample after Fe extraction by $\mathrm{H}_{2} \mathrm{SO}_{4}(1.3 \mathrm{M})$ regarding exposure period and $\left.\mathrm{B}\right)$ Concentration of Fe extracted with $\mathrm{H}_{2} \mathrm{SO}_{4}(1.3 \mathrm{M})$ in terms of exposure time.

Table 5 - Descriptive statistics of kaolinite (Kt) and gibbsite $(\mathrm{Gb})$ of area of $145 \mathrm{ha}$, at 0.0 to $0.2 \mathrm{~m}$.

\begin{tabular}{|c|c|c|c|c|c|c|c|c|c|c|}
\hline & GS & Mean & Median & Min & Max. & Var. & Skewness & Kurtosis & $S D^{(1)}$ & $\mathrm{CV}^{(2)}$ \\
\hline \multirow{3}{*}{$\mathrm{WHH}_{\mathrm{ct}}$} & 1 & $0.487 \mathrm{~b}$ & 0.478 & 0.381 & 0.600 & $1 \mathrm{E}-03$ & 0.72 & 1.98 & 0.04 & 8.54 \\
\hline & $\|$ & $0.484 b$ & 0.477 & 0.359 & 0.700 & $1 \mathrm{E}-03$ & 1.07 & 2.65 & 0.05 & 12.31 \\
\hline & III & 0.555 a & 0.547 & 0.376 & 0.740 & $1 \mathrm{E}-03$ & 0.17 & 0.42 & 0.06 & 12.36 \\
\hline \multirow{3}{*}{$\mathrm{WHH}_{\mathrm{gb}}$} & I & $0.296 a b$ & 0.298 & 0.228 & 0.371 & $1 \mathrm{E}-03$ & -0.02 & -0.99 & 0.04 & 13.64 \\
\hline & $\|$ & 0.307 a & 0.293 & 0.232 & 0.490 & $1 \mathrm{E}-03$ & 1.60 & 2.70 & 0.05 & 17.53 \\
\hline & III & $0.270 \mathrm{~b}$ & 0.266 & 0.211 & 0.490 & $1 \mathrm{E}-03$ & 1.82 & 4.98 & 0.04 & 17.38 \\
\hline \multirow{3}{*}{$M C D_{c t}$} & I & $17.24 \mathrm{a}$ & 17.40 & 13.80 & 21.90 & 2.07 & 0.18 & 2.53 & 1.43 & 8.35 \\
\hline & $\|$ & $17.35 \mathrm{a}$ & 17.50 & 6.80 & 23.20 & 5.42 & -0.94 & 4.76 & 2.32 & 13.42 \\
\hline & III & $15.22 \mathrm{~b}$ & 15.20 & 11.30 & 22.20 & 22.20 & 0.83 & 1.81 & 1.95 & 12.83 \\
\hline \multirow{3}{*}{$M C D_{g b}$} & I & $28.70 \mathrm{~b}$ & 28.00 & 22.70 & 37.40 & 15.98 & 0.58 & 0.51 & 3.99 & 13.93 \\
\hline & $\|$ & $27.89 \mathrm{~b}$ & 28.20 & 17.00 & 36.20 & 17.93 & -0.60 & 0.23 & 4.23 & 15.18 \\
\hline & III & $31.25 \mathrm{a}$ & 31.60 & 17.10 & 39.80 & 21.07 & -0.53 & 0.41 & 4.58 & 14.67 \\
\hline \multirow{3}{*}{$\mathrm{Kt} /(\mathrm{Kt}+\mathrm{Gb})$} & I & $0.77 \mathrm{a}$ & 0.78 & 0.43 & 0.97 & $1 \mathrm{E}-03$ & -2.15 & 13.56 & 0.07 & 9.71 \\
\hline & $\|$ & $0.70 \mathrm{~b}$ & 0.70 & 0.45 & 0.84 & 1E-03 & -0.41 & 1.05 & 0.06 & 9.71 \\
\hline & III & $0.57 c$ & 0.60 & 0.22 & 0.83 & $1 \mathrm{E}-03$ & -0.58 & 2.42 & 0.09 & 16.00 \\
\hline
\end{tabular}

(1)Standard deviation; ${ }^{(2)}$ Coefficient of variation (\%);GS = geomorphic surface; Min. = Minimum; Max. = Maximum; Var. = Variance; WHH = Width at half height ( $\left.{ }^{\circ} 2 \theta\right)$; $\mathrm{MCD}=$ Mean Crystallite Dimension (nm). Values in a column followed by the same letter were not different (Tukey test, $p<0.05$ ).

Kt and Gb showed opposite behaviors. Kt had a lower degree of crystallinity in surface III, while Gb had a greater degree of crystallinity in this area (Table 5). Regarding the $\mathrm{Kt} /(\mathrm{Kt}+\mathrm{Gb})$ ratio, we observed a difference between all GS and lower values, that is, the lowest $\mathrm{Kt}$ rate over Gb was found in GS III $(p<0.05)$. However, in this study, a higher degree of crystallinity and a greater $\mathrm{Kt}$ rate with respect to $\mathrm{Gb}$ in older surfaces are related to higher sand contents in these surfaces with a consequent greater release of silica. The quartz of fine sand fraction may act as a continuous source of silica (Lepsch et al., 1977; Furian et al., 2002) keeping the high silicon activity inside favoring the formation of Kt (Lindsay, 1979) in relation to Gb. Nevertheless, in GS III, in addition to the smaller sand contents, the highest $\mathrm{Fe}_{2} \mathrm{O}_{3}$ levels favor $\mathrm{Gb}$ formation, since $\mathrm{Fe}$ contributes to prevent Kt crystallization favoring $\mathrm{Gb}$.

At larger coefficients of variation (CV) of the Gt/ $(\mathrm{Gt}+\mathrm{Hm})$ ratio contents of Fe oxides and MS were found in GS III (Table 4). We also found the presence of two soil classes in the same GS (Figure 1 and Table 1), indicating greater variability of these attributes in this GS. This is because the GS III is in a less stable landscape, corroborating studies carried out by Daniels et al. (1970), Parsons et al. (1970), Gamble et al. (1970) and Lepsch et al. (1977), who stated that soils in younger GS have greater variation in their attributes. For the attributes related to $\mathrm{Fe}$ oxides, skewness and kurtosis parameters were above 1.0; however, the mean and median of these attributes were similar without compromising the geostatistical analysis. The MS had different mean and median values and this attribute showed impairment to carry out the geostatistical analysis.

The temporal sequence of GSs was not related to the nature of the mineral fraction, but it influenced the degree of crystallinity and variability, mainly in Fe oxides. The contents of Fe oxides and MS in the soil were related to lithological variations in the area. These results emphasize the importance of knowing the stratigraphy of the ground in order to understand the relationship between cause and effect when applying the concepts and to understand GS soils as natural bodies. 
The lowest Ds values and the highest values of total porosity and microporosity were found in GS III because of the clay mineralogy of this GS (Table 6). Fe and Al oxides contribute to soil aggregation, acting as cementing agents (Lutz, 1936; Kroth and Page, 1947; Schwertmann and Kampf, 1985; Camargo et al., 2008b), increasing soil porosity and decreasing Ds. In GS III, we also observed the highest values of $\mathrm{P}_{\text {ads }}$ when compared with the other GS. The highest values of $\mathrm{P}_{\text {ads }}$ in GS III were related to higher Gt and Hm contents in the soil surface. Fe oxides adsorb phosphate ions in adsorption sites on the surface of iron oxides (Parfitt, 1978; Stumm, 1992; Persson et al., 1996). These results indicate the potential of clay mineralogy characterization for the understanding of physical and chemical properties in the soil. Thus, GSs that delimit the occurrence and crystallinity of clay minerals can be used as specific management areas, once they also delimit the behavior of soil physical and chemical properties.

The degree of crystallinity of clay minerals, the content of Fe oxides, AS in Gt and MS were spatially dependent (Table 7). The spherical model was fitted to the semivariogram of all attributes that showed spatial dependence, except for the Gt content, the Gt //Hm $+\mathrm{Gt}$ ) ratio, Fed, Feo and MS that showed the gaussian model fitted to the semivariograms. For attributes that showed spatial dependence at the site of 145 ha, we

Table 6 - Mean values of density (Ds), soil porosity and $\mathrm{P}$ adsorbed (Pads) at 0.00 to $0.20 \mathrm{~m}$.

\begin{tabular}{lccc}
\hline & Surface I & Surface II & Surface III \\
\hline Ds $\left(\mathrm{MG} \mathrm{m}^{-3}\right)$ & $1.59 \mathrm{ba}$ & $1.63 \mathrm{a}$ & $1.57 \mathrm{~b}$ \\
TPV (\%) & $37.42 \mathrm{ba}$ & $36.02 \mathrm{~b}$ & $38.83 \mathrm{a}$ \\
Micro (\%) & $30.49 \mathrm{~b}$ & $28.62 \mathrm{c}$ & $31.89 \mathrm{a}$ \\
Macro (\%) & $6.6 \mathrm{a}$ & $7.1 \mathrm{a}$ & $6.9 \mathrm{a}$ \\
Pads (mg kg & 422 b & $420 \mathrm{~b}$ & $559 \mathrm{a}$
\end{tabular}

Mean values in a column followed by the same letter were not different (Tukey test, $p<0.05$ ). TPV $=$ total pore volume; Micro = microporosity, Macro = macroporosity. constructed spatial distribution maps (Figures 3, 4 and 5). The maps of the DMC Gt (111 and 110) (Figures 3A and 3D) had similar patterns, where a sharp transition occured between surfaces II and III.

The Hm showed a higher degree of crystallinity (higher MCD) in GS I and the limit between GS I and GS II corresponded to the limit found in the field (Figure 2C). The maps for the contents of Gt, Hm, Fed, Feo and MS showed similar spatial distributions, lower values for GSs I and II and higher values in GS III (Figures 4A, 4B, $4 \mathrm{D}, 4 \mathrm{E}, 4 \mathrm{~F})$. Kt had the highest degree of crystallinity in GSs I and II, and the Gb showed the highest degree of crystallinity in GS III. These results corroborate the mean difference for both minerals (Figures 5A and 5B).

The maps confirmed the age of GS III (youngest) and its unstable position in the landscape, mainly with regard to the contents of Fe oxides (Gt, Hm, Fed and Feo) and SM. In this GS, we found a greater spatial variability of attributes, agreeing with the variability found in simple statistics (Table 4). In GS III, more than one class of values was found for these attributes whereas in GSs I and II, only one class was found.

To evaluate the effect of scale variability of clay mineralogy, statistical and geostatistical analyses were performed over an area of 500 ha, where the transect occupied the central position as we analyzed the contents of Gt and $\mathrm{Hm}$, ratio Gt/(Gt $+\mathrm{Hm})$, Fed, Feo and MS (Table 8 and Figure 5). The same attributes that presented spatial dependence in the 145 ha area also presented spatial dependence in the 500 ha area.

A correspondence of the spatial distribution pattern between contents of Gt Hm, Fed, Feo and SM and boundaries of GS (Figure 6) was also observed in the 500-ha area. GSs conditioned the variability of $\mathrm{Fe}$ oxides on a large scale, indicating that these mappings can be used in homogeneous areas, since these oxides have many attribute covariates of agronomic interest.

Table 7 - Parameters of the models fitted to the semivariograms of attributes studied in the area of 145 ha.

\begin{tabular}{|c|c|c|c|c|c|c|c|}
\hline Attributes & Model & $\mathrm{C}_{0}$ & $\mathrm{C}_{0}+\mathrm{C}_{1}$ & GDE & Range (m) & $\mathrm{R}^{2}$ & RSS \\
\hline $\mathrm{MCD}_{\mathrm{Gt110}}$ & Spherical & 37.17 & 65.54 & 0.57 & 267.76 & 0.398 & 374.0 \\
\hline $\mathrm{MCD}_{\mathrm{Gt111}}$ & Spherical & 56.40 & 112.90 & 0.50 & 721.00 & 0.866 & 680.0 \\
\hline $\mathrm{MCD}_{\mathrm{Hm} 110}$ & Spherical & 86.34 & 134.56 & 0.64 & 772.18 & 0.719 & 955.0 \\
\hline $\mathrm{MCD}_{\mathrm{Hm} 012}$ & Spherical & 124.60 & 187.95 & 0.66 & 968.73 & 0.717 & 2088.0 \\
\hline AS Gt & Spherical & 27.84 & 46.50 & 0.60 & 485.77 & 0.630 & 201.0 \\
\hline Gt & Gaussian & 72.05 & 152.42 & 0.47 & 744.25 & 0.941 & 919.0 \\
\hline $\mathrm{Hm}$ & Spherical & 54.90 & 281.80 & 0.19 & 1144.00 & 0.968 & 3084.0 \\
\hline $\mathrm{Gt} /(\mathrm{Gt}+\mathrm{Hm})$ & Gaussian & 56E-04 & 0.012 & 0.46 & 604.00 & 0.987 & $1.2 \mathrm{E}-06$ \\
\hline Fed & Gaussian & 38.70 & 311.10 & 0.12 & 1054.00 & 0.988 & 1560.0 \\
\hline Feo & Gaussian & 1.09 & 2.53 & 0.43 & 591.00 & 0.916 & 0.45 \\
\hline MS & Gaussian & 0.04 & 0.41 & 0.09 & 800.61 & 0.936 & $2 \mathrm{E}-02$ \\
\hline $\mathrm{MCD}_{\mathrm{Ct}}$ & Spherical & 2.69 & 6.63 & 0.41 & 1053.00 & 0.652 & 11.5 \\
\hline $\mathrm{MCD}_{\mathrm{Gb}}$ & Spherical & 23.80 & 36.66 & 0.65 & 927.63 & 0.946 & 14.7 \\
\hline $\mathrm{Ct} /(\mathrm{Ct}+\mathrm{Gb})$ & Spherical & 49E-05 & $18 \mathrm{E}-04$ & 0.27 & 297.00 & 0.557 & 8.0E-07 \\
\hline
\end{tabular}

$\mathrm{C}_{0}=$ nugget effect; $\mathrm{C}_{0}+\mathrm{C}_{1}=$ sill; $\mathrm{R}^{2}=$ determination coefficient model; $\mathrm{GSD}\left(\mathrm{C}_{\mathrm{d}} /\left(\mathrm{C}_{0}+\mathrm{C}\right){ }^{*} 100\right)$ degree of spatial dependence (moderate: between 25 and $75 \%$, low: $>75 \%$ and strong: $\leq 25 \%$ ); RSS = residuals sum of square; MCD = Mean Crystallite Dimension; AS = aluminum substitution; Fed = iron oxides extracted by dithionite-citrate-bicarbonate; Feo = iron extracted by ammonium oxalate; MS = magnetic susceptibility; Hm = Hematite; Gt = Goethite; Kt = kaolinite; Gb = gibbsite. 


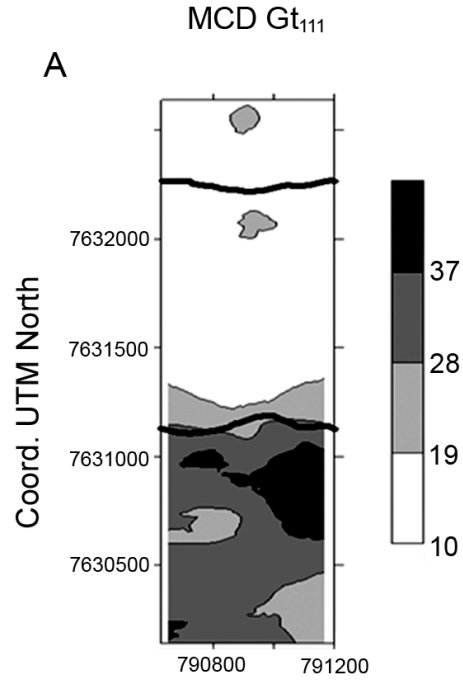

Coord. UTM East

MCD Gt $t_{110}$

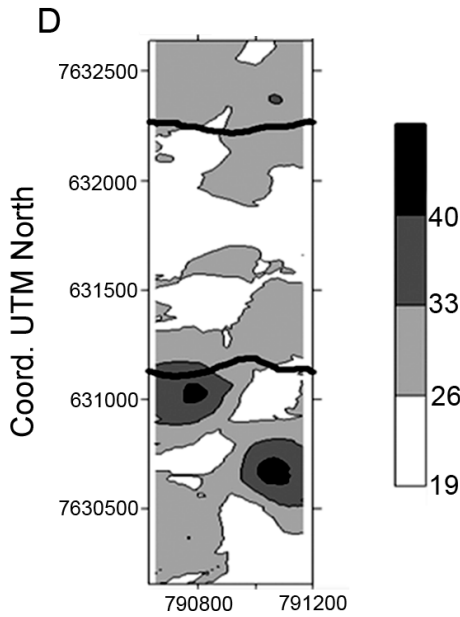

Coord. UTM East

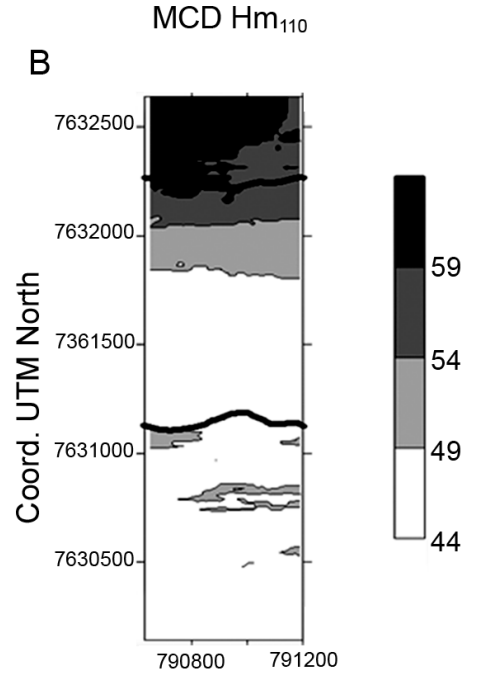

Coord. UTM East

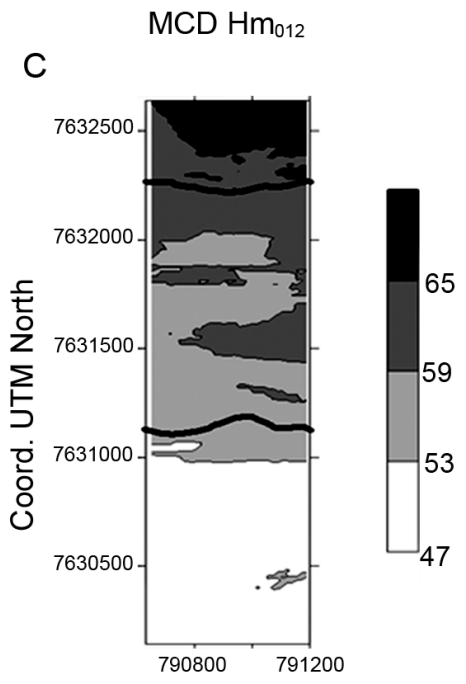

Coord. UTM East

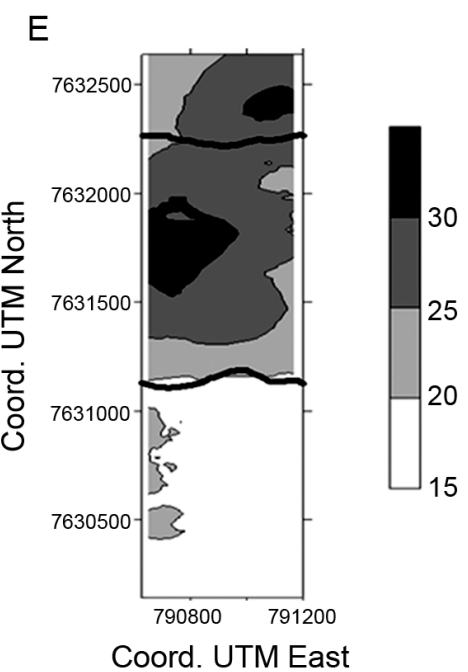

Figure 3 - Maps of Mean Crystallite Dimension [MCD (nm)] of goethite and hematite and Al substitution [AS (molAl \%)] in Gt of 145 ha.

Table 8 - Descriptive statistics of the attributes the study area (area 500 ha) at 0.0 to $0.2 \mathrm{~m}$.

\begin{tabular}{|c|c|c|c|c|c|c|c|c|c|}
\hline Atributos & Mean & Median & Min & Max. & Var. & Skewness & Kurtosis & $\mathrm{SD}^{(1)}$ & $\mathrm{CV}^{(2)}$ \\
\hline $\mathrm{Hm}^{(3)}$ & 46.38 & 37.60 & 9.30 & 132.80 & 518.84 & 1.48 & 2.17 & 22.77 & 49.10 \\
\hline $\mathrm{Gt}^{(3)}$ & 29.25 & 23.40 & 6.50 & 92.90 & 280.83 & 1.56 & 2.40 & 16.75 & 57.28 \\
\hline $\mathrm{Gt} /(\mathrm{Gt}+\mathrm{Hm})$ & 0.281 & 0.280 & 0.04 & 0.59 & 0.010 & 0.32 & -0.08 & 0.10 & 37.14 \\
\hline $\mathrm{Fe}_{d}^{(3)}$ & 50.96 & 43.50 & 18.60 & 112.10 & 338.43 & 1.28 & 1.06 & 18.39 & 36.09 \\
\hline $\mathrm{Fe}_{0}^{(3)}$ & 5.83 & 5.60 & 2.2 & 11.1 & 2.5 & 0.77 & 0.53 & 1.58 & 27.10 \\
\hline SM & 0.658 & 0.371 & 0.121 & 3.276 & 0.425 & 1.75 & 2.44 & 0.652 & 99.12 \\
\hline
\end{tabular}

(1) Standard deviation; (2)Coefficient of variation (\%); ${ }^{(3)} \mathrm{g} \mathrm{kg}^{-1}$. Var. = Variance; Min. = Minimum; Max. = Maximum; Hm = Hematite; Gt = Goethite; Fed $=$ iron oxides extracted by dithionite-citrate-bicarbonate; Feo = iron extracted by ammonium oxalate; MS = magnetic susceptibility $\left(10^{-8} \mathrm{~m}^{3} \mathrm{~kg}^{-1}\right) ; \mathrm{Hm}=\mathrm{Hematite}, \mathrm{Gt}=\mathrm{Goethite}$.

More than one class of values for the contents of Gt, Hm, Fed, Feo and SM (Figure 6) was found within a soil class (Figure 1, Table 1), mainly in GS III. This shows variability within mapping units that may be relevant in delimiting site-specific management areas for agricultural purposes expressed by the influence of $\mathrm{Fe}$ oxides in soil attributes.

The techniques used in this study demonstrated the bilateralism of the GS and the influence of these Fe oxides and MS, using univariate statistical and geostatistical 

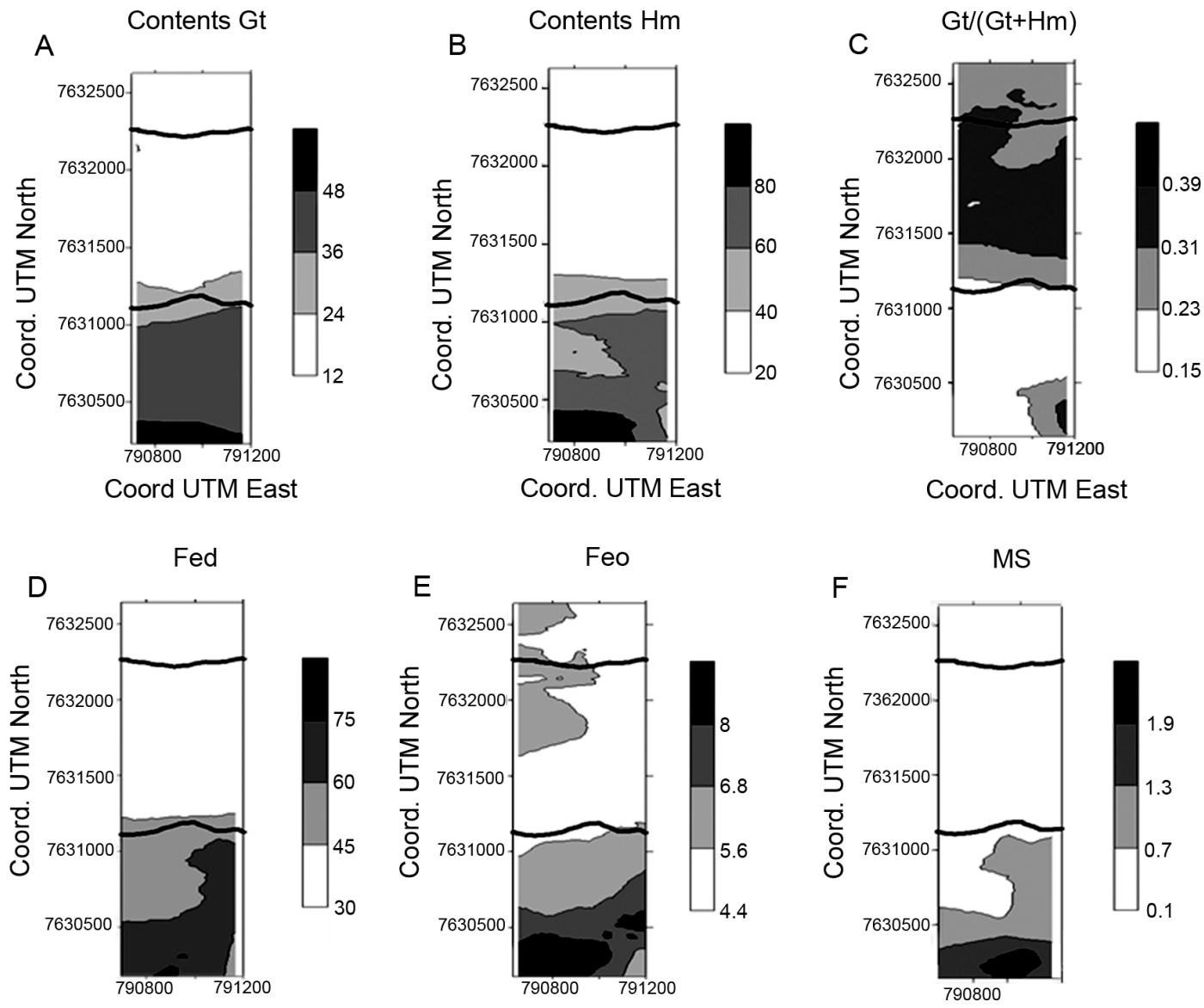

Coord. UTM East

Coord. UTM East

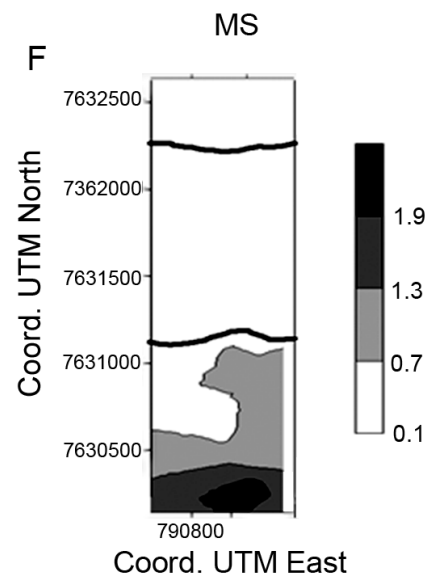

Figure 4 - Maps of Gt and $\mathrm{Hm}$ contents $\left(\mathrm{g} \mathrm{kg}^{-1}\right), \mathrm{Gt} /(\mathrm{Gt}+\mathrm{Hm})$ ratio, magnetic susceptibility [MS $\left(10^{-8} \mathrm{~m}^{3} \mathrm{~kg}^{-1}\right)$ ], Fe oxides extracted by dithionitecitrate-bicarbonate [Fed $\left.\left(\mathrm{g} \mathrm{kg}^{-1}\right)\right]$; iron extracted by ammonium oxalate [Feo $\left.\left(\mathrm{g} \mathrm{kg}^{-1}\right)\right]$ of $145 \mathrm{ha}$. Gt = goethite and $\mathrm{Hm}=$ hematite.
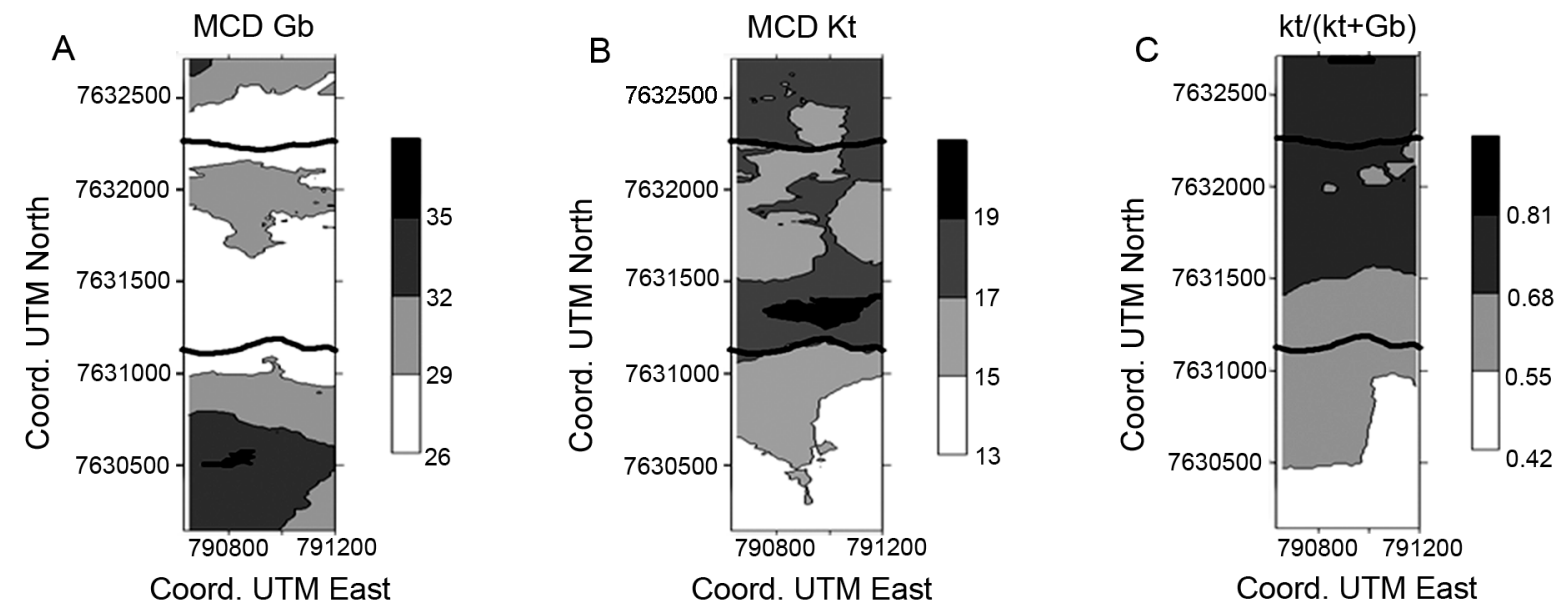

Figure 5 - Maps of Mean Crystallite Dimension [MCD (nm)] of kaolinite (Kt) and gibbsite (Gb) and Kt/(Kt+Gb) ratio of 145 ha.

analyses. They also allowed for the identification of variability within the minimum mapping unit that may help in the establishment of site-specific management areas on a detailed scale even in large areas.
The level of characterization proposed here can be used for areas with Fe contents and the presence of geomorphic surfaces similar to those studied, that recognized features in large tropical areas that control 

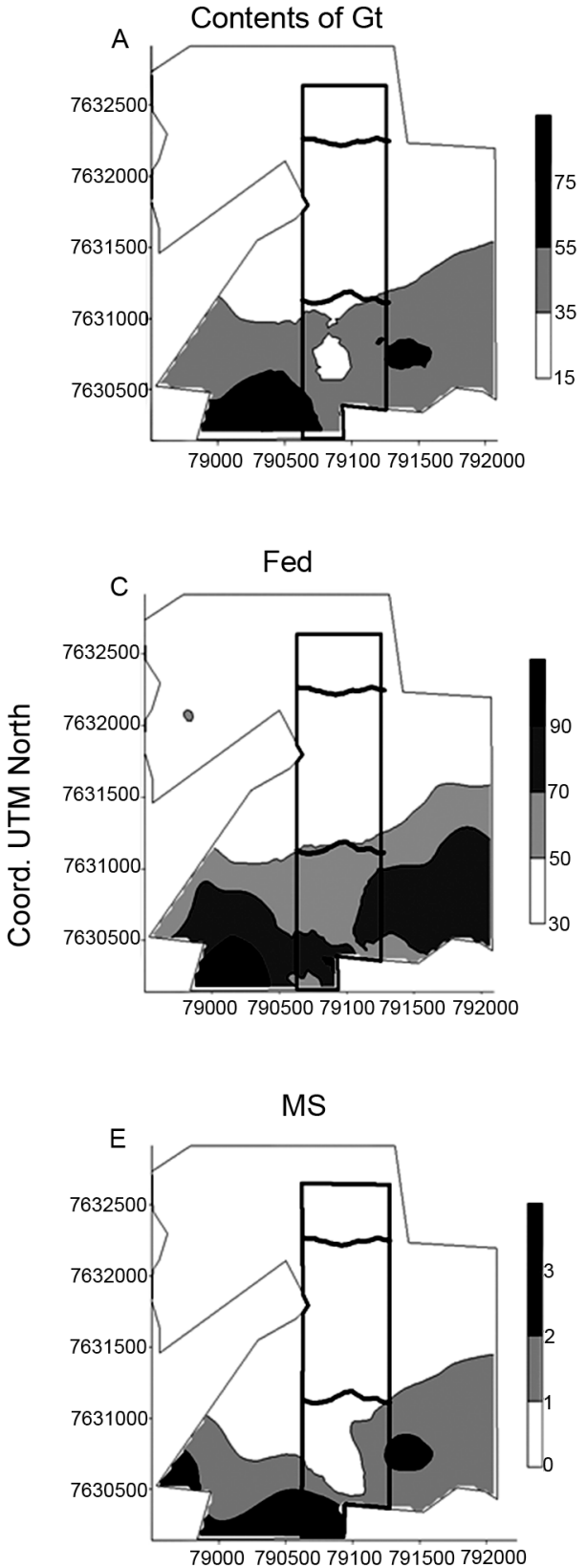
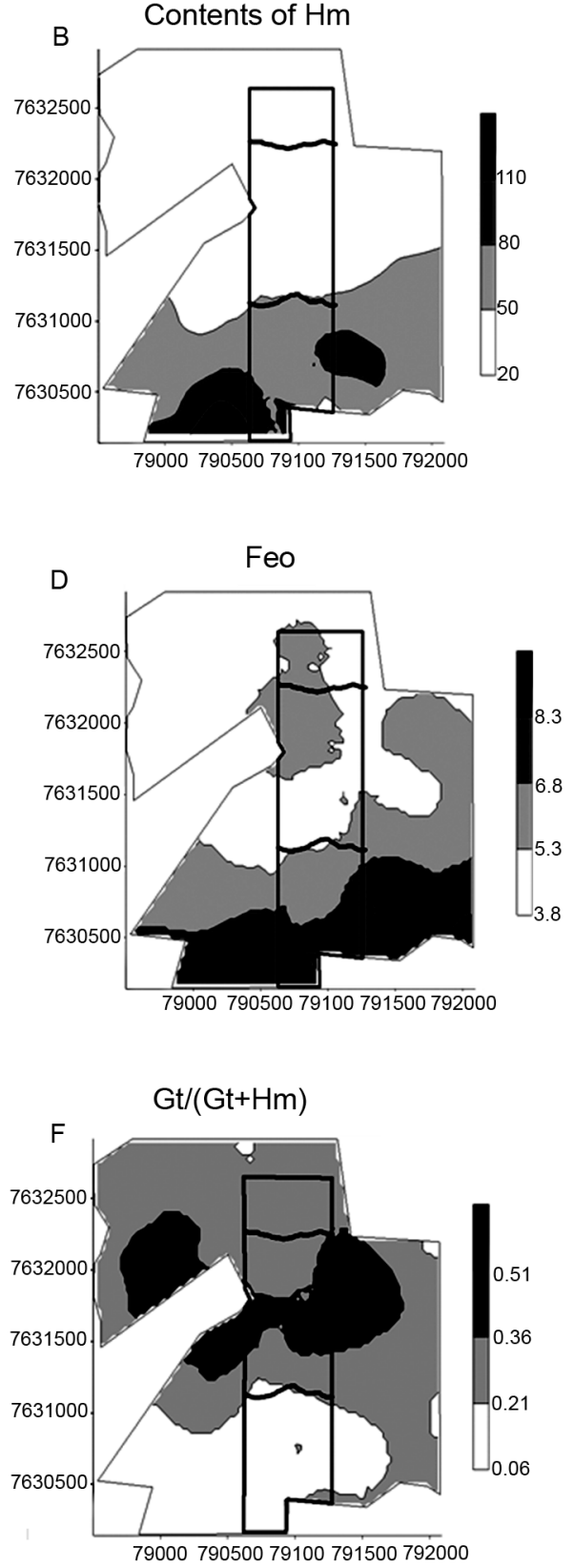

\section{Coord. UTM East}

Figure 6 - Maps of Gt and Hm contents $\left(\mathrm{g} \mathrm{kg}^{-1}\right)$, Gt $/(\mathrm{Gt}+\mathrm{Hm})$ ratio, magnetic susceptibility [MS $\left.\left(10^{-8} \mathrm{~m}^{3} \mathrm{~kg}^{-1}\right)\right]$, Fe oxides extracted by dithionitecitrate-bicarbonate [Fed $\left(\mathrm{g} \mathrm{kg}^{-1}\right)$ ]; Fe extracted by ammonium oxalate [Feo $\left(\mathrm{g} \mathrm{kg}^{-1}\right)$ ] of 500 hectares. Gt = goethite, hematite = Hm. Rectangle in the maps indicate the boundary area of 145 ha and geomorphic surfaces.

spatial variability. The use of MS, as noted, enables this characterization to replace costly and time-consuming chemical and mineralogical soil analysis.

\section{Conclusions}

1. The nature of the clay minerals and magnetic susceptibility were dependent on the variation of the soil parent material.
2. The high values of magnetic susceptibility were associated with the presence of maghemite and magnetite of coarse size.

3. The spatial variability of crystallinity of the content of both Fe oxides, as well as the magnetic susceptibility, were dependent on the age of the geomorphic surfaces. Younger surfaces (III) showed greater spatial variability of these attributes.

4. The iron (goethite and hematite) and aluminum 
(gibbsite) oxides in geomorphic surface III influenced the low values of soil density and high values of total pore volume, micropores and $\mathrm{P}$ adsorption.

5 . The characterization of the spatial variability of $\mathrm{Fe}$ oxides and susceptibility allowed for the delineation of homogeneous areas.

\section{Acknowledgements}

To FAPESP (São Paulo Research Foundation), for the scholarship granted to the 1st author, and to $\mathrm{CNPq}$ (National Council for Scientific and Technological Development), for the research grants to the $2^{\text {nd }}$ and $3^{\text {rd }}$ authors.

\section{References}

Borggaard, O.K.; Szilas, C.; Gimsing, A.L.; Rasmussen, L.H. 2004. Estimation of soil phosphate adsorption capacity by means of a pedotransfer function. Geoderma 118: 55-61.

Camargo, L.A.; Marques Jr, J.; Pereira, G.T.; Alleoni, L.R.F. 2013. Spatial correlation between the composition of the clay fraction and contents of available phosphorus of an Oxisol at hillslope scale. Catena 100: 100-106.

Camargo, L.A.; Marques Jr, J.; Pereira, G.T.; Horvat, R.A. 2008a. Spatial variability mineralogical of an Oxisol under different landforms. I. Mineralogy of the clay fraction. Revista Brasileira de Ciência do Solo 32: 2269-2277 (in Portuguese, with abstract in English).

Camargo, L.A.; Marques Jr, J.; Pereira, G.T.; Horvat, R.A. 2008 b. Spatial variability mineralogical of an Oxisol under different landforms. II. Spatial correlation between mineralogy and aggregates. Revista Brasileira de Ciência do Solo 32: 2279-2288 (in Portuguese, with abstract in English).

Costa, A.C.; Bigham, J.M.; Rhoton, F.E.; Traina, S.J. 1999. Quantification and characterization of maghemite in soils derived from volcanic rocks in southern Brazil. Clays and Clay Minerals 47: 466-473.

Curi, N.; Franzmeier, D.P. 1984. Toposequence of Oxisols from the central plateau of Brazil. Soil Science Society of America Journal 48: 341-346.

Daniels, R.B.; Gamble, E.E.; Cady, J.F. 1971.The relation between geomorphology and soil morphology and genesis. Advances in Agronomy 23: 51-87.

Daniels, R.B.; Gamble, E.E.; Cady, J.G. 1970. Some relations among coastal plain soils and geomorphic surfaces in North-Carolina. Soil Science Society of America Proceedings 34: 648-653.

Day, P.R. 1965. Particle fraction and particle fractionation and particle-size analysis. p. 545-566. In: Black, C.A., ed. Methods of soil analysis. American Society of Agronomy, Madison, WI, USA.

Fontes, M.P.F.; Weed, S.B. 1996. Phosphate adsorption by clays from Brazilian Oxisols: relationships with specific surface area and mineralogy. Geoderma 72: 37-51.

Furian, S.; Barbiero, L.; Boulet, R.; Curmi, P.; Grimaldi, M.; Grimaldi, C. 2002. Distribution and dynamics of gibbsite and kaolinite in an oxisol of Serra do Mar, southeastern Brazil. Geoderma 106: 83-100
Gamble, E.E.; Daniels, R.B.; Nettleto, W.D. 1970. Geomorphic surfaces and soils in Black-Creek-Valley, Johnston County, North Carolina. Soil Science Society of America Journal 34: 276-281.

Grossman, R.B.; Reinsch, T.G. 2002. Bulk density and linear extensibility. p. 201-228. In: Dane, J.H.; Topp, C., eds. Methods of soil analysis: physical methods. SSSA, Madison, WI, USA.

Isaaks, E.H.; Srivastava, R.M. 1989. Applied Geostatistics. Oxford University Press, New York, NY, USA.

Jackson, M.L. 1985. Soil Chemical Analysis. 2ed. Upper Saddle River, Prentice Hall, NJ, USA.

Kämpf, N.; Schwertmann, U. 1982. Goethite and hematite in a climosequênce in Southern Brazil and their application in classification of kaolinitic Soils. Geoderma 29: 27-39.

Kämpf, N.; Schwertmann, U. 1998. Measure of the expected replacement of $\mathrm{Fe}$ by $\mathrm{Al}$ in hematite soil. Revista Brasileira de Ciência do Solo 22: 209-213 (in Portuguese, with abstract in English).

Klug, H.P.; Alexander, L.E. 1974. X-Ray Diffraction Procedures for Polycrystalline and Amorphous Materials. Wiley, New York, NY, USA.

Kroth, E.M.; Page, J.B. 1947. Aggregate formation in soils with special reference to cementing substances. Soil Science Society of America Proceedings 11: 27-34.

Lepsch, I.F.; Buol, S.W.; Daniels, R.B. 1977. Soil-landscape relationships in an area of the occidental plateau of São Paulo, Brazil. I. Geomorphic Madison surface and soil mapping units. Soil Science Society of America Journal 41: 104-109.

Lindsay, W. 1979. Chemical Equilibria in Soils. John Wiley, New York, NY, USA. Lutz, J.F. 1936. The relation of free iron in the soil to aggregation. Soil Science Society of America Proceedings 1: 43-45.

Matheron, G. 1963. Memoirs of the Office of Geological and Mining = Traité de Géostatistique Appliquée. II. Mémoires du Bureau de Recherches Géologiques et Minières. Editions Technip, Paris, France. (in French).

McBratney, A.B.; Webster, R. 1983. How many observations are needed for regional estimation of soil properties? Soil Science 135: $177-183$

McNeal, B.L.; Layfiel, D.A.; Norvell, W.A.; Rhoades, J.D. 1968. Factors influencing hydraulic conductivity of soils in the presence of mixedsalt solution. Soil Science Society of America Proceedings 32: 187-190.

Mehra, O.P.; Jackson, M.L. 1960. Iron oxide removed from soils and clays by dithionitecitrate system buffered with sodium bicarbonate. Clays and Clay Minerals 7: 1317-327.

Mesquita Filho, M.V.; Torrent J. 1993. Phosphate sorption as related to mineralogy of a hydrosequence of soils from the Cerrado region (Brazil). Geoderma 58: 107-123.

Norrish, K.; Taylor, R.M. 1961. The isomorphous replacement of iron by aluminium in soil goethites. The Journal of Soil Science 12: 294-306.

Olson, R.V.; Ellis Jr, R. 1982. Iron. In: Page, A.L., ed. Methods of soil analysis. 2. Chemical and microbiological properties. 2ed. Soil Science Society of America, Madison, WI, USA. p.301-312. (Agronomy, 9).

Parfitt, R.L. 1978. Anion adsorption by soils and soil materials. Advances in Agronomy 30: 1-5. 
Parsons, R.B.; Balster, C.A.; Ness, A.O. 1970. Soil Developpment and geomorphic surfaces, Villamentte Valley, Oregon. Soil Science Society of America Proceedings 34: 485-491.

Persson, P.; Nilsson, N.; Sjoberg, S. 1996. Structure and bonding of orthophosphate ions at the iron oxide-aqueous Interface. Journal of Colloid and Interface Science 177: 263-275.

Ruhe, R.V. 1969. Quaternary Landscapes in Iowa. Iowa State University Press, Ames, IA, USA.

Schaefer, C.E.G.R.; Gilkes, R.J.; Fernandes, R.B.A. 2004. EDS/ SEM study on microaggregates of Brazilian Latosols, in relation to $\mathrm{P}$ adsorption and clay fraction attributes. Geoderma 123 : 1-33.

Schulze, D.G. 1984. The influence of aluminum on iron oxides. VIII. Unit-cell dimensions of Al-substituted goethites and estimation of $\mathrm{Al}$ from them. Clays and Clay Minerals 32: 3644.

Schwertmann, U. 1964. Differentiation of iron oxides of the soil by extraction with ammonium oxalate-solution = Differenzierung der Eisenoxide des Bodens durch Extraction mit Ammoniumoxalat-Losung. Zeitschrift Pflanzenernahrung Bod 105: 194-202 (in German).

Schwertmann, U.; Fechter, H. 1984 The influence of aluminium on iron oxides. XI. Aluminium-substituted maghemite in soils and its formation. Soil Science Society of American Journal 48: 1462-1463.

Schwertmann, U.; Fitzpatrick R.W.; Taylor R.M.; Lewis, D.G. 1979. The influence of aluminum on iron oxides. II. Preparation and properties of Al-substituted hematites. Clays and Clay Minerals 27: 105-112.
Schwertmann, U.; Kämpf, N. 1985. Properties of goethite and hematite in kaolinitic soils of Southern and Central Brazil. Soil Science 139: 344-350.

Schwertmann, U.; Murad, E. 1983. Effect of $\mathrm{pH}$ on the formation of goethite and hematite from ferrihydrite. Clays and Clay Minerals 4: 377-284.

Schwertmann, U.; Taylor, R.M. 1989. Iron oxides. p.379-438. In: Dixon, J.B.; Weed, S.B., eds. Minerals in soil environments. 2.ed. Soil Science Society of America, Madison, WI, USA.

Soil Survey Staff. 1999. Soil Taxonomy: A Basic System of Soil Classification for Making and Interpreting Soil Surveys. 2ed. USDA-NRCS, Washington, DC, USA.

Singer, M.J.; Bowen, L.H.; Verosub, K.L.; Fine, P.; Tenpas, J. 1995. Mössbauer spectroscopy evidence for citrate-bicarbonatedithionite extraction of maghemite from soils. Clays and Clay Minerals 43: 1-7.

Stumm, W. 1992. Chemistry of the solid-water interface processes at the mineral-water and particle-water interface in natural systems. Wiley, New York, NY, USA.

Thompson, R.; Oldfield, F. 1986. Environmental Magnetism. Allen \& Unwin, London, UK.

Torrent, J.; Guzman, R.; Parra, M.A. 1982. Influence of relative humidity on the crystallization of $\mathrm{Fe}(\mathrm{III})$ oxides from ferrihydrite. Clays and Clay Minerals 30: 337-340.

Townsend, F. 1985. Geotechnical characteristics of residual soils. Journal of Geotechnical Engineering 111: 77-94.

Vieira, S.R.; Hatfield, J L.; Nielsen, D.R.; Biggar, J.W. 1983. Geostatistical theory and application to variability of some agronomical properties. Hilgardia 51: 1-75. 